'The unique flexibility and range of expressiveness of the ideophone in Bantu languages are well known. Recent observations have given some indication that the educated African often tends to use the ideophone much less frequently than the illiterate villager and that males today use it less frequently than women-a point related to the first observation, since female education is less widespread than that of males. At a recent Provincial Council meeting in the Kaonde-Lunda province of Northern Rhodesia I noticed that during the deliberations only three ideophones were used, all by one speaker. In the course of recent linguistic work, I have closely observed the speech of two females, one educated who used ideophones infrequently, and one illiterate who used them continuously and rarely uttered more than a sentence or two without an ideophone. It would be interesting to know whether other workers have noticed the same sort of thing.'

\title{
Bride-price, Bride-wealth, Dowry
}

In the discussions on African marriage, to which we continue to devote much of our space, there should be uniformity in the use of certain terms. What term should be employed for the cattle or other goods that are transferred from one group to another as an integral part of marriage? Most people are now agreed this is not a buying and a selling. Let us then avoid the use of the word 'paying'. For the same reason we dislike the word 'bride-price' and prefer, for want of a better, 'bride-wealth'. Dr. A. E. Grootaert, the eminent Belgian jurist, rightly protests against the use of dot ('dowry') and proposes titre matrimonial. Instead of payer le dot he would say constituer le titre matrimonial, and instead of rembourser le dot he would say retourner le titre matrimonial, retirer le titre matrimonial, according whether the action is by the woman's or the man's group; or annuler le titre matrimonial if no particular reference is made to either party. What would our readers, and especially the legally trained, say to adopting in English ' matrimonial title'?

\section{Marriage Ordinances for Africans}

\section{Mr. Martin Parr writes to us as follows:}

'In the July number of Africa Mr. W. Y. Turner comments on my article in the January number. He writes about 'Christian marriage', an expression which has no legal significance and which Dr. Quick (the late Regius Professor of Divinity, Oxford) and many other churchmen hold should not be used in considering the laws governing marriage. A marriage, however celebrated, can become a 'Christian marriage' if the parties have the intention, the faith and the grace to make it so. But that has nothing whatever to do with the civil law by which the marriage is contracted. Incorrect use of the term 'Christian marriage' has caused Mr. Turner to write: "In the Church of Scotland mission to the south of the protectorate the rule was adopted that Christian marriage must be only between Christians, but in the northern part of the protectorate ... Christian marriage continued to be celebrated even where only one party was Christian "- a statement the real meaning of which, I fear, eludes me.

'Mr. Turner expresses surprise that in Nyasaland an Act has been passed giving legal status to marriages of Asiatics according to their several religious tenets, while thousands of native Christians, who are demanding legal status for their marriages, are denied this right. I have not the Act to which he refers, but I suspect that the principle enacted in it is that the parties may be married according to the laws of the community to which they belong: in some Asiatic communities the civil law may be identical with the religious law. I cannot believe that any Christian African is denied legal status for his marriage according to the civil law of the community to which he belongs, a civil law which in Nyasaland is not the ecclesiastical law of the Church of England or the Church of Scotland; this is not 